\title{
SHOULD CORPORATION LAW INFORM ASPIRATIONS FOR GOOD CORPORATE GOVERNANCE PRACTICES-OR VICE VERSA? ${ }^{\dagger}$
}

\section{E. NORILAN VEASEY ${ }^{H}$}

Yesterday I had the honor to give the keynote address in Stockholm, Sweden, to the Organization for Economic Cooperation and Development ("OECD"). Some of what was discussed there is relevant here.

At the OECD Conference, all European countries and many other countries around the world were represented in a kind of United Nations setting. The conferees were exchanging ideas on issues of company law reform. One theme emerged as dominant: Many conferees were yearning for a judicial system like the well-developed system of judge-made fiduciary duty law we have in Delaware. They all seemed to believe our system works well, even with all its warts. They were amazed by, and envious of, our expertise, fact-specificity, and the speed of our decisions. But they seemed to be resigned to the reality that their judicial systems were not set up to replicate Delaware's.

\section{THE ENABLING MODEL}

An overarching global debate is whether corporate law rules should be mandatory or enabling. I agree with those scholars whose thesis is that the enabling model is the better economic model for the stockholders. The enabling model, patterned after the Delaware approach, is based on a few fundamental statutory guideposts and latitude for private ordering, with primary reliance on self-governance centered around judicial decisionmaking in applying fiduciary duties to fact-intensive settings.

A word of caution is that the judge-made law must not be of a freewheeling or ad hoc quality. It must involve a disciplined and stable stare decisis analysis based on precedent and a coherent economic rationale. The private ordering aspect of it must provide ex ante the

$\dagger$ Address at the University of Pennsylvania Law School Symposium on Norms and Curporate Law, December 8, 2000.

it Chief Justice of the Delaware Supreme Court. 
contractual stockholder protections deemed important, as distinct from ex post judicial rewriting of the contractual framework.

At the end of the day the enabling model-at least in Delawarerests on a two-fold trust in the judiciary and in the board of directors. That trust, in turn, is predicated on two fundamental principles: The first is character-by that I mean expertise, diligence, good faith, independence, and professionalism. The second is a sound economic rationale dedicated to the best interests of stockholders.

First, the courts. Investors, as the owners of corporations, have certain expectations of the role of courts in the enforcement of fiduciary duties. The judicial process is a key ingredient in the overall corporate construct among the four parties involved-the stockholders, directors, management, and state government (legislative, executive, and judicial). Courts should be prompt, clear, predictable, stable, and economically coherent.

Second, the directors. All the attributes of character are important. But perhaps the most effective stockholder protection device is the independence of directors. Stockholders vote for directors and expect proper governance from them. The expectation is a strong bond of trust vested in the directors. Courts enforce that trust. At the same time, courts should be reluctant to interfere with business decisions and should not create surprises or wild doctrinal swings in their expectations of directorial behavior.

The duties of directors are defined in broad outline by the enabling act. The fiduciary aspects of the directors' duties are fleshed out by the case law. That is the corporate law dimension. The remainder of the corporate governance regime consists of private ordering, norms, and aspirations of well-motivated directors to achieve best practices with the precatory encouragement of courts.

Modern and enlightened corporation law driven primarily by judicial decisions is a remarkable vehicle in our jurisprudence. There is a significant self-governing aspect to the corporation law in that daily functions of the enterprise are based largely on norms-i.e., nonlegally enforceable governance mechanisms. Self-governance works for the most part because of the sensitivity of directors to do what is right, what is professional, what is honorable, and what is profitable. There are also negative motivators such as peer pressure, "shaming," and fear of lawsuits. 


\section{THE ROLES OF THE BOARD}

Let us focus on the various roles of the board. Under statutory law, the business and affairs of the corporation are to be managed by or under the direction of the board of directors. The board hires management-personified by the $\mathrm{CEO}$-and management makes most of the "enterprise decisions"-(e.g., should the plant be in Peoria or Pittsburgh?). Enterprise decisions are to be distinguished from "ownership decisions." The interests of stockholders are affected directly by ownership decisions, which can happen in corporate mid-life, but usually come as part of final period decisions (such as mergers).

The question then becomes: How should corporate law-nestled in the enabling mode-approach the judicial oversight of the board? Complete lack of judicial review of all corporate conduct is clearly not an option. A generalized, regulatory review of internal affairs or corporations is not an option either, in my view. Judicial review is triggered by a case that is usually brought by a stockholder in some individual or representative capacity. The scope of judicial review varies with the subject matter. Generally speaking, enterprise decisions receive deferential judicial review, as do some ownership decisions. Interested director transactions, hostile takeovers, change of control transactions, and some ownership decisions may receive more intense judicial scrutiny.

Courts do not reach out to monitor boards or to resolve disputes. Courts, therefore, are like the clams sitting in the water waiting for some activity to come their way. That said, I think judges can and should perform a service by speaking out to encourage best corporate practices that could have a prophylactic benefit in minimizing the exposure of directors to liability.

When a controversy comes their way, the courts must approach the resolution realistically, fairly, efficiently, and based on a coherent economic and jurisprudential rationale. In this connection, I would like to mention just four issues: (1) independence of directors; (2) best interests of stockholders; (3) duty of care; and (4) best corporate practices.

\section{A. Independence of Directors}

Under Delaware fiduciary duty law, the independence of directors becomes critical in some discrete areas. For example, two areas are interested director or controlling stockholder transactions and 
derivative litigation. There are others, of course. But there is no "bright line" or "litmus test" for independence. It must be decided on a case-by-case basis. Generally speaking, the more the board is dominated by purely independent directors, the more likely it is that board action will find a safe harbor from liability in many settings. Thus, the relevant inquiries are: Independent for what purpose? Independence from whom?

Recently the derivative case of Brehm v. Eisner was before the Delaware Court of Chancery and the Supreme Court. ${ }^{1}$ The case involved the board of Walt Disney Company. The Chancellor decided that a majority of the board was independent for purposes of the demand requirement. The issue there was fact-specific, issue-specific, and director-specific. The Chancellor approached the issue pragmatically and analytically. ${ }^{2}$ We did not disturb this holding on appeal, although we remanded the case for other reasons.

In the Supreme Court, on appeal, the Council of Institutional Investors asked us to adopt a defined and generalized standard of independence. We thought the proposal was interesting, but we found it unnecessary to address the question. ${ }^{3}$

Their proposal, among other things, would have us create by the common law a standard whereby there would be a presumption that a director was not independent if she fell into certain categories. Specifically, the Council defines an "independent director" as someone whose "only non-trivial professional, familial or financial connection to the corporation or its CEO is his or her directorship."

To clarify what types of relationships are "non-trivial," the Council has gone on to specify the following circumstances as ones that create a presumption of nonindependence:

- where the director has been employed by the corporation or an affiliate in an executive capacity;

- where the director is, or in the past two years has been, an employee or owner of a firm that is a paid adviser or consultant to the corporation, its affiliate, or the CEO;

- where the director is employed by, or has a five percent or greater ownership interest in, a significant customer or supplier;

${ }^{2}$ Brehm v. Eisner, 746 A.2d 244 (Del. 2000); In re Walt Disney Co. Derivative Litig., 731 A.2d 342 (Del. Ch. 1998).

In re Walt Disney Co. Derivative Litig., 731 A.2d at 354-61.

${ }^{3}$ Brehm, 746 A.2d at 256-58. 
- where the director is employed by, or has a five percent or greater ownership interest in, a debtor or creditor of the corporation if the amount owed exceeds one percent of the corporation's or the third party's assets;

- where the director has, or in the past two years has had, a personal services contract with the CEO, the corporation, or one of its affiliates;

- where the director is employed by, or serves as an officer or director of, a nonprofit corporation, foundation, university, or other organization that receives significant grants or endowments from the corporation or one of its affiliates;

- where the director is a relative of an executive of the corporation or one of its affiliates; and

- where the director is part of an interlocking directorate in which the CEO or other executive officer of the corporation serves on the board of another corporation that employs the director.

In my view, the foregoing criteria, if adopted voluntarily by a corporation, would provide a reliable and consistent basis for determining whether a director should be deemed independent. Such a result may well be a desired goal of most institutional investors. But it is not the province of the courts to "legislate" or otherwise impose such rules. Moreover, I doubt that the Delaware Legislature would find such rules appropriate for a statutory provision as part of the enabling act which is the Delaware General Corporation Law.

The inquiry in the Disney case was not whether we "liked" the composition, behavior, and decisions of Disney's board as alleged in the Complaint. That determination is not for the courts. It is a decision for the stockholders to make in voting for directors, in urging other stockholders to reform or oust the board, or in making individual buy-sell decisions involving Disney securities. Codes of best practices or corporate bylaws (like those of General Motors, for example)-not judicial fiat-are the appropriate intracorporate vehicle to establish this type of protocol.

There may be a paradox on the issue of the desirability of independent directors. On the one hand, independent directors know less than insiders about a firm, have less stake in the decision and, therefore, less incentive to get things right. What is the right balance of these considerations? Are investors necessarily better off economically with majority-independent boards? For some firms, boards dominated by insiders may be better because people with more 
time (and their money on the line) may well do better jobs. But I do not think that should be the norm for public companies, although in some cases a blended board balanced between independent directors and knowledgeable insiders may be optimal. This just proves that, in this area as with other governance models, there is no "one size fits all."

Although independence of directors may not necessarily guarantee the best economic return to stockholders, I think the better view, generally, is that a worthwhile goal is to have a significant majority of independent directors on the board. Independence offers to investors some assurance that the governance process has integrity.

\section{B. Best Interests of Stockholders}

Our jurisprudence is full of the rubric that directors should act in the honest belief that the action taken is in the best interests of the corporation and its stockholders. A question kept coming up at the OECD Conference in Stockholm on the convergence of the interests of stockholders and other stakeholders and the potential that stockholders and other stakeholders often have varying interests.

The OECD Principles differ from Delaware law in the articulation of the board's obligation to stakeholders (employees, creditors, community, etc.). Delaware's jurisprudence holds that the interests of stockholders are primary and may not be trumped by that of other constituencies, although those interests may be considered if congruent with the interests of the stockholders. The concern I expressed at the OECD Conference is that too much emphasis placed on stakeholders or other constituencies diffuses the primary focus of directors-the best economic interests of stockholders.

Let us step back for a minute and look at the economic reality of corporate life. Corporations do indeed function according to norms-most of the time. Litigation is a costly last resort and should be reserved for bad, aberrational behavior. Why? That is part of the theory of derivative litigation. It is well explained in the cogent dicta of Judge Ralph Winter of the Second Circuit in the 1982 case of Joy $v$. Nort $^{4}$ and those of former Delaware Chancellor Allen in the 1996 case of Gagliari $v$. TriFoods International, Inc. ${ }^{5}$ I will try to paraphrase some of these dicta and amalgamate them with my own views of the

5683 A.2d 1049, 1052 (Del. Ch. 1996). 
economic rationale of the corporate construct.

Stockholders expect their investment to be profitable, but they undertake the risk of bad business judgment by the directors or the management. Investors have many investment opportunities other than stock and these opportunities (like bonds) may be less vulnerable than stockholdings to mistakes in judgment by corporate management. Equity investors need not invest in a particular corporation. Stockholders can and do select among investments partly on the basis of management. As a result, the business judgment rule recognizes the stockholders' tacit acceptance of the risk of bad business decisions.

Stockholders' investment interests, across the full range of their diversifiable equity investments, will be maximized if corporate directors and managers honestly assess risk and reward and accept for the corporation the highest available risk-adjusted returns that are above the firm's cost of capital.

After-the-fact litigation is a wasteful device to deal with questionable business decisions. The circumstances surrounding the directors' decisions are not easily reconstructed in a courtroom years later. The board must encounter risks and confront uncertainty in a tight time period. A decision that seems reasoned at the time made may seem dead wrong when viewed years later against a background of hindsight knowledge.

Some of these points are well made by Professor Hamermesh in his recent article entitled, Why I Do Not Teach Van Gorkom. ${ }^{6}$ His thesis is that a proper analysis of the rationale for the tendency to accord deference to directors in the due care area is the recognition by sophisticated courts of the value to investors of managerial risk-taking. This is a good segue that brings me now to the subject of the duty of care.

\section{Duty of Care}

The duty of care raises many questions about decisionmaking process, oversight and duty to monitor, personal liability, exemptions and defenses, injunctions and transactional justification, gross negligence and recklessness, and the borders between lack of due care and lack of good faith.

"Lawrence A. Hamermesh, Why I Do Not Teach Van Gorkom, 34 GA. L. REV. 477, $482(2000)$. 
But the overarching philosophical issue has to do with the best economic interests of stockholders. Directors will tend to be riskaverse if they must assume some degree of personal risk relating to ex post claims of derivative liability for any resulting corporate loss occasioned by a business decision gone bad. Directors need not worry under our law for mistakes of judgment-even "stupid" ones.

As to business decisions, the business judgment rule has the effect of freeing directors and the CEO to take business risks. This is the way we paraphrased the business judgment rule in the Disney case: Directors' decisions will be respected by courts unless the directors are interested or lack independence relative to the decision, do not act in good faith, act in a manner that cannot be attributed to a rational business purpose, or reach their decision by a grossly negligent process.

Courts do not measure, weigh, or quantify directors' judgments. We do not even decide if board decisions are "reasonable" in this context. Due care in the decisionmaking context is process due care only. Irrationality-not unreasonableness-is the outer limit of the business judgment rule. Irrationality may implicate a lack of good faith or be the functional equivalent of waste.

The relative freedom given directors under the business judgment rule has a counterpoint that is also of benefit to stockholders. It is decidedly in the stockholders' economic interest that courts firmly enforce violations of the duty of loyalty. In such cases there may be severe damage awards against directors or officers who act in their own self-interest and not in the interest of the firm. A recent example is a per curiam decision by the Delaware Supreme Court released last week in Intermational Telecharge, Inc. v. Bomarko, Inc. ${ }^{7}$ In Bomarko, we affirmed a decision after trial by Vice Chancellor Lamb finding a faithless fiduciary liable for substantial damages for violating his duty of loyalty.

There is, therefore, an exposure of directors for fraud, disloyalty, law violation, bad faith, and the like. There is also a theoretical exposure to personal liability in damages for gross negligence in process due care that forfeits the protection of the business judgment rule and requires the fiduciary to show entire fairness. The same may be true for sustained inattention or utter failure to have law compliance systems, for example.

The potential for liability may be only theoretical because of

${ }^{7} 766$ A.2d 437 (Del. 2000) (per curiam). 
certain statutory protections. There are at least two Delaware statutes that offer the directors some protection in the due care area.

First, under one Delaware statute, directors may be

fully protected in relying in good faith upon the records of the corporation and upon such information, opinions, reports or statements presented to the corporation by any of the corporation's officers or employees, or committees of the board of directors, or by any other person as to matters the member reasonably believes are within such other person's professional or expert competence and who has been selected with reasonable care by or on behalf of the corporation. ${ }^{8}$

Second, there is another statutory exemption that, when adopted in the corporate charter by stockholders, exempts directors from liability for negligence. In 1986, Delaware took the lead in adopting section 102(b)(7) of the general corporation law after the Delaware Supreme Court's 1985 decision in Smith v. Van Gorkom." Most state legislatures have since authorized, and stockholders of most corporations have taken advantage of, this type of an exoneration of directors of liability for duty of care violations. It is interesting that stockholders have willingly and overwhelmingly adopted these statutory protections for their directors. On the other hand, many stockholders would prefer to eliminate or substantially curtail "defensive measures" such as poison pills often installed by the board and used by directors at the corporate end period, primarily in a hostile takeover context. Moreover, charter amendments that would provide some takeover protections, such as a staggered board of directors, are a "hard sell."

What is the reason for this "phenomenon" that stockholders favor eliminating liability of directors for lack of due care but are opposed to defensive measures? It is not really a surprising phenomenon. It is quite understandable and predictable. Stockholders generally do not want directors to worry about negligence lawsuits because these suits are costly to the firm and distract the directors and officers from their mission-formation of capital and turning a profit to benefit stockholders.

The investors have said to the directors, in effect: "Don't worry about personal liability in damages for negligence or even gross negligence; we will not only exempt you from such threats, but we will also provide you with indemnification and insurance protection, just 
in case. You are expected to devote your energies to doing good economic work for the firm, and that is to our benefit."

But the stockholders likewise have said, in effect: "We do not excuse you from liability in damages for breach of your duty of loyalty, bad faith, intentional misconduct, improper personal benefit, etc. Nor do we like it when you erect draconian barriers that may inhibit an outside offer for our stock at a premium."

Thus personal liability in damages for due care violations is not a practical worry for directors in their daily midstream enterprise decisions. But it can be important, particularly in end period or ownership decisions for four reasons.

First, equitable relief. The statutory exemption from personal liability in damages for negligence does not preclude injunctive or other equitable relief for due care violations in the transactional justification calculus.

Second, the requirement of good faith. A director must always act in good faith, and section 102(b) (7) does not exonerate directors from liability for acts or omissions not in good faith or for violations of the duty of loyalty. So this raises the question: When is an act or omission so egregiously lacking in due care or so reckless that it evidences a lack of good faith? No director wants to be a defendant in a case testing those doctrinal borders.

Third, economic interests. Even if there are no personal liability concerns, a high-profile lack of due care by directors could undermine stockholder confidence. This could depress the stock price, cause the directors to be ousted at the next election of directors, or may lead to the rare exercise of the stockholders' statutory right of removal of the directors.

Fourth, personal integrity. Directors are, on the whole, honorable people who want to do the correct, professional thing and don't want their reputations injured. My sense is that, notwithstanding the statutory exoneration from liability for due care violations, it is the professional integrity of directors that drives them to do a good and careful job.

\section{Best Corporate Practices}

All good corporate governance practices include compliance with statutory law and case law establishing fiduciary duties. But, as we said in the Disney case, the law of corporate fiduciary duties and remedies for violation of those duties are distinct from the aspirational goals of 
ideal corporate governance practices.

Aspirational ideals of good corporate governance practices for boards of directors that go beyond the minimal legal requirements of the corporation law are highly desirable, often tend to benefit stockholders, might be a "safe harbor" in some cases, sometimes reduce litigation, and can usually help directors avoid liability. But they are not required by the corporation law and do not necessarily define standards of liability.

There are many models of codes of good corporate practice that have voluntarily been adopted by corporations. Those of General Motors and Campbell Soup are two examples. This is one area where the OECD countries and the United States corporate governance protocols are "on the same page." By voluntarily adopting best practices, OECD countries can sometimes finesse the problem that their systems usually lack meaningful resort to the courts. United States companies are well advised to adopt best corporate practices to stay out of court. The courts like that, too, because we already have crowded dockets and would prefer not to have so many cases.

We see today an emphasis on due care processes as well as the preponderance of independent directors as part of good corporate governance practices. Indeed these practices are becoming the norm, though they may not be required.

So corporate law does, I believe, inform good corporate practices. Furthermore, I believe it advances a social good for courts to encourage such aspirations.

The same may be true in reverse. That is, modern trends in good corporate governance may become such well-established norms that the failure to follow the trends could conceivably result in liability in an egregious case. So good corporate practice may inform corporate law. A colleague and I hinted at that in a law review article over twenty years ago when I was in private practice. ${ }^{10}$ In 1996, former Chancellor Allen, in dictum in the Caremark case suggested that because the federal sentencing guidelines contained an incentive for a good oversight program, there was almost an expectation that boards should have one and the utter failure to do so might be problematic."

Therefore, exposure to personal liability in damages for violation

"E. Norman Veasey \& William E. Manning, Codified Standard-Safe Harbor or Uhcharted Reef? An Analysis of the Model Act Standard of Care Compared with Delaware Law, 35 Bús. LAW. 919 (1980).

"In $w^{\prime}$ Caremark Int'l Inc. Derivative Litig., 698 A.2d 959, $969-70$ (Del. Ch. 1996). 
of the duty of care might seem far-fetched except in a very unusual factual setting. On the other hand, liability for duty of loyalty violations can be quite real and quite severe. Nevertheless, why should we (and I include the judges in the term "we") not exhort boards to have the best, professional corporate practices?

\section{CONCLUSION}

As long as we have judge-made law as the core of Delaware's corporate law system, we must focus on ways to improve the reliance of investors and courts on boards of directors operating with integrity at the heart of that system. Thus, we need to seek aspirational norms for good corporate practice. I have seven suggestions of my own for boards of directors. These are recommended protocols offered as an aspirational matter only. They do not necessarily drive liability considerations, and they do not portend how a case will be decided. Nevertheless, they may reflect some developing norms of corporate behavior. The seven suggestions are:

First, there should be a heavy majority of purely independent directors on every board. There are several definitions in various models of guidelines that corporations should consider adopting voluntarily.

Second, the board should be engaged in actual governance, and not merely act as advisors' to the CEO. This does not mean that the board runs the operations of the company (normally it should not). It means directors are in control of the policy of the firm, and the managers work for them.

Third, the directors should meet face-to-face frequently throughout the year and spend substantial time on their homework. A minimum of at least one hundred hours per year on routine matters on each board has been suggested and seems reasonable, in my view. Of course more may be required in time of crisis, and directors should not become so overcommitted that they cannot deal adequately with crises.

Fourth, the directors should limit to a reasonable number the major boards on which they serve. What is a reasonable number depends on the extent to which each director is able to carry out his or her responsibilities to each board in a professional manner, leaving room for crisis management when necessary.

Fifth, naturally, the board should have audit, compensation, and nominating committees consisting solely of independent directors, 
independently advised. Moreover, the independent directors should regularly evaluate the $\mathrm{CEO}$ and they should meet with each other alone in executive session on a regular basis.

Sixth, the board should establish and monitor reasonable law compliance programs.

Seventh, the board should carefully review disclosure documents for which they have direct responsibility to ensure that all material information reasonably available is disclosed to the relevant audience.

I hope it is clear that these suggestions are purely aspirational and not necessarily liability-related. At best, they may be in the nature of safe harbors in certain circumstances. In my view, they are becoming the norms and the reasonable expectations of stockholders. 
